\title{
INCOMMENSURABLE LEGAL CULTURES: INDIGENOUS LEGAL TRADITIONS AND THE COLONIAL NARRATIVE
}

\section{Kirsten Manley-Casimir*}

In this paper, the author argues that the non-Indigenous legal system has historically exerted and continues to exert violence on Indigenous legal traditions by insisting that its interpretation of law is authoritative and excluding alternative interpretations. Relying on Robert Cover's theories, she asserts that both nonIndigenous and Indigenous legal traditions are based on mythology, narratives and particularized language which support the different normative values that characterize the cultures from which they arise. Non-Indigenous judges may refuse to exert violence by recognizing the value inherent in and accepting the incommensurability of Indigenous legal traditions.

Dans le présent document, l'auteure soutient que le système de justice non indigène a depuis toujours attisé et continue d'attiser la violence à l'endroit des traditions juridiques indigènes en répétant que leur interprétation du droit est dictatoriale et en excluant les interprétations non conventionnelles. Se fondant sur les théories de Robert Cover, l'auteure affirme que les traditions juridiques tant indigènes que non indigènes reposent sur la mythologie, sur des narrations et sur un langage particularisé qui soutiennent les différentes valeurs normatives qui caractérisent les cultures dont elles émergent. Les juges non indigènes pourraient refuser d'encourager la violence en reconnaissant la valeur inhérente des traditions juridiques indigènes et en acceptant leur incommensurabilité.

\section{INTRODUCTION}

Indigenous cultures in Canada are rich with mythology, sacred narratives, languages, and oral traditions that have sustained their communities for generations.' Prior to and through their experiences of colonization, Indigenous

$\mathrm{PhD}$ Candidate, University of British Columbia Law School. In her dissertation she is advocating for a reformulation of the doctrine of Aboriginal title by drawing on principles supported by a variety of sources, including Canadian, international and Indigenous laws. She is currently working as a Grants Officer at the Law Foundation of Ontario [LFO]. The author would like to thank the following people for constructive feedback that greatly improved this paper: Michael Manley-Casimir, two anonymous reviewers and the editorial staff at the WYAJ. All errors and omissions are solely attributable to the author and none of the views expressed are representative of the LFO's views on these issues.

1 In this paper, I use the terms 'Indigenous' to refer to all those peoples that self-identify as such within Canada. In my use of this term, I recognize the great diversity in cultural values and beliefs 
peoples have constructed their vision of law within their unique normative worlds. In so doing, Indigenous peoples have developed complex legal systems based on values particular to their cultures. These legal systems continue to exist despite the Canadian state's insistence that its vision of the law is authoritative.

The recognition of incommensurability between the non-Indigenous ${ }^{2}$ legal system and Indigenous legal traditions ${ }^{3}$ may contribute to the survival of Indigenous cultures and the flourishing of Indigenous legal traditions within Canada. ${ }^{4}$ Indigenous legal traditions reflect the values unique to Indigenous communities and help Indigenous peoples locate themselves in their normative worlds. In this paper, I argue that both the non-Indigenous legal system and Indigenous legal traditions are heavily informed by and reflective of the narratives, mythology, language, and cultural values of the society in which such systems arose. This historical and cultural contingency has led to the evolution of radically different legal systems with correspondingly different mythologies, narratives, language and values. I also argue that the non-Indigenous legal system has historically exerted and continues to exert violence on Indigenous peoples and legal systems through a privileging of the narratives, mythology, language and cultural values of Eurocentric communities. ${ }^{5}$ Finally, I assert that Indigenous legal traditions are incommensurable to the non-Indigenous legal system; as a result, Indigenous claims may be more appropriately resolved through the creation of alternative culturally appropriate forums.

between and among the various communities. For a discussion of the diversity of Indigenous cultures see Gerald Alfred, Heeding the Voices of our Ancestors: Kahnawake Mohawk Politics and the Rise of Native Nationalism (Toronto: Oxford University Press, 1995) at 12 [Alfred, Heeding the Voices]; see also Mary Ellen Turpel, "Aboriginal Peoples and the Canadian Charter of Rights and Freedoms: Interpretive Monopolies, Cultural Differences" (1989-1990) 3 Can Hum Rts YB 6 at 146 [Turpel, "Interpretive Monopolies"].

2 I use the term "non-Indigenous" to refer to people, values, and institutions associated with nonIndigenous Canadian culture. I deliberately choose this term to position Indigenous peoples, cultures, and institutions as the norm against which dominant culture is measured. I hope that in positioning Indigenous peoples at the centre, I create more balance in non-Indigenous people's perception of Indigenous peoples and cultures.

3 For a detailed discussion of Indigenous legal traditions, see Val Napolean, "Thinking About Indigenous Legal Orders", Research Paper for the National Centre for First Nations Governance (June 2007), online: National Centre for First Nations Governance $<\mathrm{http} / / /$ fngovernance.org/ncfng research/val napoleon.pdf $>$; see John Borrows, "Indigenous Legal Traditions in Canada", Report for the Law Commission of Canada (January 2006), online: Government of Canada <http://publications.gc.ca/collections/collection_2008/lcc-cdc/JL2-662006E.pdf>; see John Borrows (Kegedonce), Drawing Out Law: A Spirit's Guide (Toronto: University of Toronto Press, 2010); and see James (Sa'ke'j) Youngblood Henderson, "Dialogical Governance: A Mechanism of Constitutional Governance" (2009) 72 Sask L Rev 29.

4 As will become clear, this recognition may not take the form of incorporating Indigenous legal traditions within the existing structures of the Canadian legal system but instead may require different culturally appropriate forums for the meaningful expression and recognition of such legal traditions.

5 Due to space constraints, I am not able to discuss the way in which cultural violence shifts into physical violence. For a detailed discussion of this shift, see Frantz Fanon, The Wretched of the Earth (New York: Grove Weidenfeld, 1963). 


\section{CONTEXT AND CAVEATS}

Before I begin, an important caveat must be highlighted - in order for Indigenous legal traditions to flourish, it is essential that Indigenous cultures continue to survive. Indigenous peoples must have the ability to live in accordance with their cultural values as a precondition to creating and practicing law in a way that is meaningful. Due to the history of colonization and governmental policies of assimilation, including the residential schools legacy, ${ }^{6}$ Indigenous peoples within Canada are poorer, have lower educational levels, ${ }^{7}$ have limited opportunities for gainful employment and experience higher levels of social problems within their communities. ${ }^{8}$ The material conditions of Indigenous communities ${ }^{9}$ often make focusing on larger political issues secondary to mere physical and cultural survival. As a result, ameliorating the material conditions of Indigenous communities constitutes the most important priority to ensure the survival of such cultures and corresponding legal traditions.

\section{THE NON-INDIGENOUS LEGAL SYSTEM AND INDIGENOUS LEGAL TRADITIONS}

Both the non-Indigenous and Indigenous legal systems have characteristics that support the normative cultural values of the particular community from which the legal systems emerge. In this section, I outline the central characteristics of the non-Indigenous legal system in order to ground the comparison and analysis between the two systems that follows.

\section{A. The Non-Indigenous Legal System}

The non-Indigenous legal system is based on Eurocentric cultural values. This system relies on the belief that the only legitimate legal authority emanates from the state. This state-centrism derives its legitimacy from international law, which is founded upon the sovereignty of state members. ${ }^{10}$ A related foundational value of the non-Indigenous legal system is that laws are written and coded by the state

6 For a detailed history of the Indian Residential Schools Legacy in Canada, see online: Truth and Reconciliation Commission of Canada <www.trc.ca〉.

7 It is important to highlight that this statement is true in relation to the Western educational system but does not reflect achievement levels within traditional Indigenous teachings.

8 For a detailed study on the effects of colonization on Indigenous peoples within Canada, see the Royal Commission on Aboriginal Peoples (Ottawa: Canada Communications Group Publishing, 1996) [RCAP], online: Indian and Northern Affairs Canada <http://www.collectionscanada.gc.ca/webarchives/2007111-5053257/http://www.aincinac.gc.ca/ch/rcap/sg/sgmm_e.html $>$; see also Rodolfo Stavenhagen, "Report of the Special Rapporteur on the Situation of Human Rights and Fundamental Freedoms of Indigenous People. Addendum. Mission to Canada" Doc.\#E/CN.4/2005/88/Add.3 (Geneva: United Nations Commission on Human Rights, 2004) at 10, online: United Nations Human Rights <http://www2.ohchr.org/english/issues/Indige-nous/rapporteur/visits.htm>.

9 As discussed below, the material conditions facing Indigenous communities also affect the way such communities have made and continue to make law.

10 It is important to note that Antony Anghie argues that this notion of sovereignty deliberately excluded Indigenous communities; see Antony Anghie, Imperialism, Sovereignty and the Making of International Law (Cambridge: Cambridge University Press, 2004) at 27. 
and that this form of law is authoritative." State law in this view is beneficial, legitimate and provides social and political stability.

The non-Indigenous legal system is characterized by the analytic method, which is preoccupied with concepts and the search for the identity of the rule. In his discussion of Hegel, William Conklin highlights that the focus on concepts and reasoning was Hegel's way of differentiating thinking beings from the stateless society of a tribe. ${ }^{13}$ In this view, tribal members are juxtaposed with thinking beings; concepts therefore offer humans an opportunity for thinking that helps them escape the constraints of nature. ${ }^{14}$

The analytic method is also preoccupied with the search for the identity of the rule. Conklin asserts that because legal theory has never been able to convincingly elucidate why human-made laws should have authority and are legitimate, the origin of such laws cannot be interrogated..$^{15}$ As a result, the common law is preoccupied with identifying rules and norms that characterize the legal system. ${ }^{16}$ Similarly, Peter Fitzpatrick argues that the state itself is empty and lacks a coherent form. ${ }^{17} \mathrm{He}$ asserts that law is self-generating in relying on rules, doctrines, principles, and values that sustain the very existence of the legal order. ${ }^{18}$ As such, the non-Indigenous legal system is actually constituted by the rules, principles and doctrines that underlie it.

The non-Indigenous legal system is also constructed as objective and universal. Conklin points out that when interpreting law, judges attempt to get inside the thought plan of the historical author or legislator and purge themselves of all subjective feelings in order to do so. ${ }^{19}$ The idealisation of objectivity is a key component of Eurocentric conceptions of justice. ${ }^{20}$ Closely related to objectivity, the non-Indigenous legal system is also founded on the belief that the values and laws that it enforces are universally applicable. ${ }^{21}$

The non-Indigenous legal system therefore is characterized by state-centrism in which state law is constructed as authoritative. Through written and coded laws, that state regulates the lives of its members through the ideals of objectivity and universal values. Courts support this vision of state-centric law by using the

11 William E Conklin, The Invisible Origins of Legal Positivism: A Re-Reading of a Tradition (Boston: Kluwer Academic Publishers, 2001) at 34 [Conklin, Invisible Origins].

12 Stuart Scheingold, The Politics of Rights: Lawyers, Public Policy and Political Change, $2 \mathrm{~d}$ ed

(Ann Arbor: University of Michigan Press, 2004) at 3; see also Roberto Mangabeira Unger, What Should Legal Analysis Become? (New York: Verso, 1996) at 36.

13 William Conklin, Hegel's Laws: The Legitimacy of a Modern Legal Order (Stanford: Stanford Law Books, 2008) at 58 [Conklin, Hegel's Laws].

$14 \quad$ Ibid at 58.

15 Conklin, Invisible Origins, supra note 11 at 38.

16 Ibid

17 William Conklin, Book Review of Law as Resistance: Modernism, Imperialism, Legalism by Peter Fitzpatrick, (2009) 27(1) Windsor YB Access Just 229 at 229.

18 Ibid at 230.

19 Conklin, Invisible Origins, supra note 11 at 38.

20 Patricia A Monture, Locating Aboriginal Peoples in Canadian Law: One Aboriginal Woman's Journey through Case Law and the Canadian Constitution (LLM Thesis, York University, 1998) [unpublished] at 64. [Monture, Journey]

21 Conklin, Hegel's Laws, supra note 13 at 76. 
analytic method, which is preoccupied by concepts and the search for the identity of the rule. These manifestations of law are idealized and juxtaposed with those of decentralized societies, such as the majority of Indigenous communities within Canada.

\section{The Mythology of the Non-Indigenous Legal System}

The image of the non-Indigenous legal system as rational, objective, universal and purified of mythology, narrative and collective memories is being challenged in much contemporary legal analysis. Peter Fitzpatrick, for example, argues that Eurocentric legal systems are based on "the mythology of European identity founded in an opposition to certain myth-ridden "others"," Similarly, Conklin argues that European legal theories are founded upon an untranslatable rupture between state-centric law and chaos and savagery. ${ }^{23}$ These theorists reveal the way in which non-Indigenous law is based on mythology and narratives that have excluded Indigenous peoples and legal traditions.

Several theorists also expose the contingency of the non-Indigenous legal system and undermine the claim that the system is universal, objective and rational. Conklin highlights the way in which laws, which are variable, socially contingent and ultimately violent are disguised as universal and neutral by their apparent objectivity and association with the divine order. ${ }^{24}$ Through the construction of Eurocentric laws as universal, Indigenous legal traditions are dichotomized as "pre-legal" or "primitive". ${ }^{25}$ As such, Indigenous legal traditions are excluded from consideration within the non-Indigenous legal system.

In his examination of the development of international law, Antony Anghie argues that the current formulation of international law developed in response to the novel circumstance of colonizing new continents inhabited by Indigenous peoples. $^{26}$ International legal principles were based on an idealisation of European values and universal standards of civilization that excluded Indigenous cultures. ${ }^{27}$ Similarly, Julie Evans argues that international law, "[f]ar from being fully formed in Europe and applied to the colonies as a pre-determinative force" evolved in response to global and local contexts that shifted over time and place. ${ }^{28}$ These contexts included competition between rival Imperial powers seeking to justify violence and discrimination against Indigenous peoples in order to dispossess them of their traditional lands. ${ }^{29}$ These theorists reveal the way in which a system of law that is considered universal, rational and objective is in fact contingent and biased.

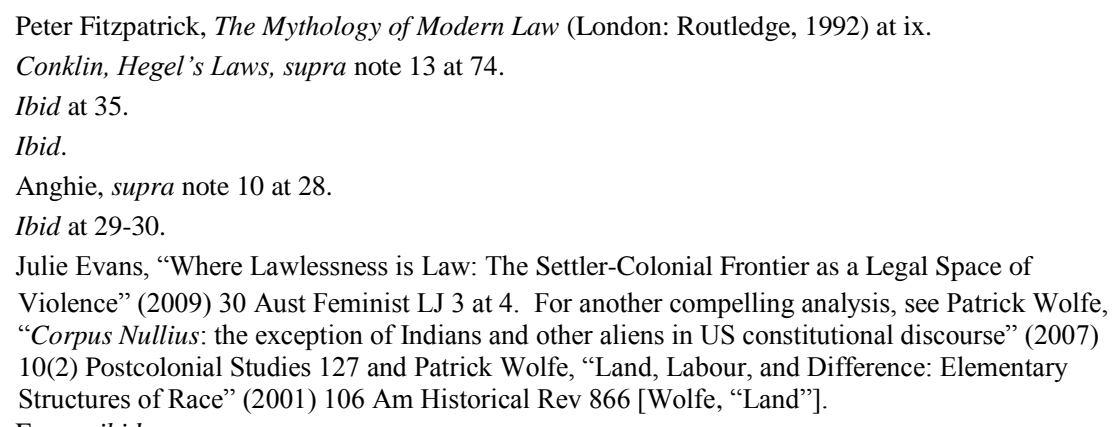


The idealized image of the non-Indigenous legal order as universal and objective is supported by the colonial narrative, which privileges Eurocentric ideas on the creation and legitimacy of law and marginalizes Indigenous visions of law. The colonial narrative tells a story of enlightened Europeans taming the vast, uninhabited (by civilized societies), lawless wilderness of North America and bringing civilization to the Indigenous peoples. By contrast, Indigenous narratives paint a different picture of the colonizing of North America that, as will be discussed below, create powerful counternarratives to the settlement of Canada.

The mythology, narratives and collective memories underpinning the nonIndigenous legal system work together to rationalize and create the illusion of a universal, neutral and objective law. This mythology serves to legitimize and replicate non-Indigenous and devalue Indigenous cultural values and legal systems. Having briefly outlined the characteristics of the non-Indigenous legal system, I now turn to a fulsome discussion of Indigenous legal traditions.

\section{B. Indigenous Legal Traditions}

Robert Cover's theory of law is particularly helpful in thinking through the relationship between Indigenous legal traditions and the non-Indigenous legal system. Cover asserts that all of us "inhabit a nomos - a normative universe" that "we constantly create and maintain a world of right and wrong, of lawful and unlawful, and of valid and void". ${ }^{31}$ He argues that "the creation of legal meaning 'jurisgenesis' - takes place through an essentially cultural medium". ${ }^{32}$ In inhabiting a particular nomos, communities create their own normative legal systems based on their cultural values.

\section{Jurisgenesis in Indigenous Communities}

Within what is now Canada, there are many examples of jurisgenerative Indigenous communities who created legal systems that pre-existed ${ }^{33}$ the nonIndigenous legal system. In the Haudenosaunee Nation, for example, a complex legal system existed that set out principles of government decision-making, consensus, veto powers, and proportional representation. ${ }^{34}$ Similarly, the Plains Blackfoot and Cree, had highly developed cultural and legal concepts that structured their understanding that the land could not be privately owned but was to be shared with all creation. ${ }^{35}$ Just as the Haudenosaunee and Plains First Nations

30 Robert M Cover, "The Supreme Court 1982 Term Foreword: Nomos and Narrative" (1983-1984) 97 Harv L Rev 4 at 4 [Cover, "Nomos"]. In expanding on the idea of nomos, Cover says at 9: "A nomos, as a world of law, entails the application of human will to an extant state of affairs as well as toward our visions of alternative futures. A nomos is a present world constituted by a system of tension between reality and vision."

Ibid at 4.

32 Ibid at 11. Indigenous legal traditions have adapted to meet the challenges presented by colonialism to Indigeneous cultures. Colonialism and its corresponding external restrictions therefore have shaped Indigenous cultures in a way that has affected the creation of legal meaning.

33 I use the word "pre-existed" or "pre-existing" in this paper to mean prior in time.

34 Alfred, Heeding the Voices, supra note 1 at 77-78. The Haudenosaunee Nation is also known as the Iroquois Nation.

35 Leroy Little Bear, "Aboriginal Paradigms: Implications for Relationships to Land and Treaty Making" in Kerry Wilkins, ed, Advancing Aboriginal Claims: Visions/Strategies/Directions (Saskatoon: Purich Publishing, 2004) at 37. 
developed systems of law, so other Indigenous peoples developed legal systems to govern their communities.

Contemporary Indigenous communities continue to create legal meaning through their adaptation to their colonial experiences. This jurisgenesis continues even under the colonially imposed instrument of the Indian Act. ${ }^{36}$ The Spallumcheen Indian Band, for example, passed a by-law in 1980 providing for a comprehensive child welfare regime that applied to all Band children. The by-law provided that the Band has the responsibility for the welfare of Band children and exclusive jurisdiction over any child custody proceedings involving a Band child regardless of the child's residence. Neither the federal nor provincial government have challenged the legality of the by-law; in fact, courts have upheld the validity of the by-law in two cases. ${ }^{37}$ Other examples of jurisgenesis include the use of Indigenous legal traditions to choose the Chief and Council in the majority of Bands within Canada. ${ }^{38}$ Similarly, some First Nations use and recognize customary marriages and adoptions.

The Spallumcheen's child welfare by-law, the existence of customs to choose the leaders of Bands, and the recognition of customary marriages and adoptions are examples of the non-Indigenous legal system's recognition that First Nations within Canada are jurisgenerative communities. ${ }^{40}$ This recognition highlights the respect given to First Nations to generate autonomous norms to govern their communities. ${ }^{41}$ This recognition is limited, however, in the fact that these instances of jurisgenesis are seen as appropriate and non-threatening to the status quo and nation state's power. ${ }^{42}$

36 RSC 1985 [Indian Act].

37 See Alexander v Maxime, [1995] BCJ No 367; see also $S(E G) v$ Spallumcheen Band Council, [1999] 2 CNLR 318.

38 Shin Imai, Aboriginal Law Handbook, $2^{\mathrm{d}}$ ed, (Scarborough, Ontario: Carswell Thomson, 1999) at 168-169.

39 Ibid at 218 \& 228. Here Imai also cites cases in which non-Indigenous courts have recognized some customary marriages and adoptions.

40 In the 1876 case of Connolly $v$ Woolrich, (1867), 17 RJRQ 75, 11 LCJur 197 (Que SC), online: Union of British Columbia Indian Chiefs Digital Collections <http://gsdl.ubcic.bc.ca/collect/firstna1/archives/HASH015e/4954-e019.dir/doc.pdf〉, Justice Monk of the Quebec Superior Court upheld the validity of a Cree marriage and awarded the son of that marriage a share in Mr. Connolly's estate. Mr. Connolly had married Ms. Pas-de-Nom, a Cree woman, cohabitated with her for 28 years and had six children. Mr. Connolly then returned to Montreal where he married his second cousin, Ms. Woolrich and had two children. Upon Mr. Connolly's death, he bequeathed his estate to Ms. Woolrich and upon her death she bequeathed the estate to her children. Justice Monk held that the common law recognized the validity of Mr. Connolly's Cree marriage to his first wife since no Imperial legal regime was in effect in that area at the time of the marriage.

41 Cover, "Nomos" supra note 30 at footnote 94, cites Santa Clara Pueblo v Martinez, 436 US 49 (1978), as illustrative of the fact that "respect for a degree of norm-generating autonomy has...traditionally been incident to the [United States] federal government's relations with Indian tribes."

42 For cases where the Supreme Court of Canada has not been willing to recognize Aboriginal commercial rights, see $R v$ Sparrow [1990] 1 SCR 1075; $R v$ Gladstone [1996] 2 SCR 723; $R v$ Marshall [1999] 3 SCR 456; $R$ v Marshall [1999] 3 SCR 533; and Mitchell $v$ Minister of National Revenue [1999] 1 CLNR 112 [Mitchell]. For related academic criticism, see André Goldenberg, “'Salmon for Peanut Butter': Equality, Reconciliation and the Rejection of Commercial Aboriginal Rights" (2004) 3 Indigenous LJ at paras 73-77; see also Gordon Christie, "A Colonial 
Jurisgenerative communities create legal meaning even when their legal interpretations do not correspond to those of the state. ${ }^{43}$ First Nations within Canada are continually involved in the creation of legal meaning that is not recognized as valid under Canadian law. In $R v$ Pamajewon, $^{45}$ for example, the Shawanaga and Eagle Lake First Nations both passed by-laws dealing with lotteries. Neither by-law was passed pursuant to the Indian Act nor did either First Nation have a provincial lottery licence. When charged under the Criminal Code, ${ }^{46}$ the Shawanaga First Nation claimed the inherent right to self-government and the Eagle Lake First Nation claimed a right to be self-regulating in its economic activities. The Supreme Court of Canada held that gambling was not protected under s. 35 of the Constitution Acts ${ }^{47}$ as neither First Nation had proven that gambling was an integral part of their distinctive cultures ${ }^{48}$ at the time of contact. ${ }^{49}$

Both the Shawanaga and Eagle Lake First Nations alleged that the driving force for enacting the lottery by-laws was to supplement inadequate federal funding for housing and social services. ${ }^{50}$ Both First Nations were responding to economic duress directly caused by colonial policies - policies that continue to

Reading of Recent Jurisprudence: Sparrow, Delgamuukw and Haida Nation" (2005) 23 Windsor YB Access Just 17.

43 There are many examples of Indigenous communities and individuals creating law and coming into conflict with the non-Indigenous legal system. These cases range from fishing and hunting without a licence (see $R v$ Adams [1996] 3 SCR 101; see also $R v$ Seward [1999] 3 CLNR 299); to bringing goods across the border without paying duty (see Mitchell, ibid); to asserting Aboriginal title to their traditional territories (see Calder v British Columbia (Attorney-General) [1973] SCR 313; see also Delgamuukw v British Columbia [1997] 3 SCR 1010 [Delgamuukw]).

44 Two examples of Indigenous jurisgenerative activity that have resulted in violence from the state include the stand off in Oka and at Ipperwash. For details on the Oka dispute see Patricia Begin, Wendy Moss \& Peter Niemczak, Background Paper: The Land Claims Dispute at Oka (Library of Parliament Research Branch, September 1990); and see Centre for Research-Action on Race Relations, The Oka Crisis of 1990; Lessons from the Crisis and Proposals of the Future (March 1991). For details on the Ipperwash dispute see Peter Edwards, One Dead Indian: the Premier, the Police, and the Ipperwash Crisis (Toronto: Stoddart, 2001); and see The Honourable Sidney B Linden, Commissioner, Ipperwash Inquiry (30 May 2007), online: Attorney General Ontario <http://www.attorney-general.jus.gov.on.ca/inquiries/ipperwash/index.html>. [1996] 2 SCR 821 [Pamajewon].

46 RSC 1985, c C-46.

47 The Constitution Acts 1867-1982, Schedule B, Department of Justice (Ottawa: Canada Communications Group Press, 1989).

48 Pamajewon, supra note 45 at para 29. The "integral to the distinctive culture test" has been the subject of heavy academic criticism for freezing Aboriginal rights at a point that pre-dates contact and minimizing the constitutional protection of Aboriginal rights; see e.g. Gordon Christie, "Law, Theory and Aboriginal Peoples" (2003) 2 Indigenous LJ 67 at paras 43-54 [Christie "Law, Theory"]; see Chilwin Chienhan Cheng, "Touring the Museum: A Comment on R. v. Van der Peet", (1997) 55 UT Fac L Rev 419; see Russel Lawrence Barsh \& James Youngblood Henderson, "The Supreme Court's Van der Peet Trilogy: Naive Imperialism and Ropes of Sand" (1997) 42 McGill LJ 993; and see Emily Luther, "Whose 'Distinctive Culture'? Aboriginal Feminism and R. v. Van der Peet" (2010) 8:1 Indigenous LJ 27.

49 The Supreme Court of Canada held that part of the reason the Shawanaga and Eagle Lake First Nation's claims failed was because they could not show that gambling took place on a twentieth century-scale. This test has been criticized in much academic commentary: see e.g. John Borrows, "The Trickster: Integral to the Distinctive Culture" (1997) 8:2 Forum Constitutionnel 27 at 30 .

50 Highlighting this point is not intended to detract from their argument that gaming was historically an important part of their culture. 
limit the socio-economic conditions of Indigenous communities within Canada. The fact that the Shawanaga and Eagle Lake First Nations created the lottery bylaws as a direct response to the legacy of colonialism does not detract from the validity of the jurisgenerative capacity of both First Nations. Pamajewon provides a powerful example of the way in which colonialism continues to shape jurisgenesis within Indigenous communities.

The jurisgenesis that has taken place within Indigenous communities as a result of their colonial experiences has been the result of the interaction between the colonizers' and Indigenous cultures. When two cultures come into contact, both cultures change as a result of cultural interaction. ${ }^{51}$ In contexts of domination, it becomes necessary for colonized peoples to adapt to new circumstances. As James Clifford observes,

[g]roups negotiating their identity in contexts of domination and exchange persist, patch themselves together in ways different from a living organism. A community, unlike a body, can lose a central "organ" and not die. All the critical elements of identity are in specific conditions replaceable: language, land, blood, leadership, religion. Recognized, viable tribes exist in which any one or even most of these elements are missing, replaced, or largely transformed.

The experiences of colonization have resulted in generations of damage to the cultural, social, economic and jurisdictional fabric of Indigenous communities. Due to the necessity of survival in the face of assimilative social and legal practices, Indigenous communities within Canada continue to redefine their normative worlds in ways that support their continued cultural existence.

Both forms of jurisgenesis - the revival of old legal traditions and the development of new legal traditions in the face of the colonial experience - are equally valid forms of legal interpretation. As Sally Falk Moore argues:

Whether rituals, laws, rules, customs, symbols, ideological models, and so on, are old and legitimated by tradition, or newly forged and legitimated by a revolutionary social source, they constitute the explicit cultural framework through which the attempt is made to fix social life, to keep it from slipping into the sea of indeterminacy. ${ }^{53}$

The continued transformation of Indigenous legal traditions is necessary for the cultural survival of Indigenous peoples within Canada. Without the creation and

51 See Katherine Hermes, “'Justice Will Be Done Us': Algonquian Demands for Reciprocity in the Courts of European Settlers" in Christopher L Tomlins \& Bruce H Mann, eds, The Many Legalities of Early America (London: University of North Carolina Press, 2001) 123 at 144; see also James Clifford, The Predicament of Culture (Cambridge, MA: Harvard University Press, 1988).

52 Clifford, ibid at 338.

53 Sally Falk Moore, Law as Process: An Anthropological Approach (London: Routledge \& Kegan Paul, 1978) at 41. 
adaptation of such legal systems, the unique normative communities that make up Indigenous peoples within Canada would disappear.

\section{Law as a Bridge between Nomos and Narrative}

The creation of law is a dynamic process. Rather than conceiving of law as a static set of rules from which objective principles can be derived, Cover asserts:

Law...is a bridge in normative space connecting [our understanding of] the "world-that-is"...with our projections of alternative "worlds-that-might-be".... In this theory, law is neither to be wholly identified with the understanding of the present state of affairs nor with the imagined alternatives. It is the bridge - the committed social behavior which constitutes the way a group of people will attempt to get from here to there. Law connects "reality" to "alternity" constituting a new reality with a bridge built out of committed social behavior.

Law, therefore, is constituted by a group's committed social behaviour, through which the group attempts to move towards its alternative vision of reality. This committed social action is necessary to create legal meaning since "[a] legal world is built only to the extent that there are commitments that place bodies on the line., ${ }^{, 55}$

Cover's conception of law as a dynamic process mirrors Indigenous conceptions of law. Indigenous legal systems are characterized by dynamic performance rather than by the interpretation of a static set of rules. As James (Sákéj) Youngblood Henderson clarifies:

[Aboriginal] legal systems... are conceptually self-sustaining and dynamically self-generating. They symbolize a form of order that is simultaneously heard, seen, felt, and savoured through holistic ceremonies and performances.... Through dynamic synthesis, Aboriginal jurisprudences and laws exist not as things or nouns or rules, but rather as overlapping and interpenetrating processes or activities that represent teachings, customs, and agreements... Aboriginal peoples understand their jurisprudences as a liquid force that lives through conduct, rather than as something that has to be written or produced by specialized thought or legal training. It is more a matter of dynamic processes than a matter of logic, causality, or structural theory.

54 Robert Cover, "The Folktales of Justice: Tales of Jurisdiction” (1984-1985) 14 Capital UL Rev 179 at 181 [Cover "Folktales"].

55 Robert Cover, "Violence and the Word" (1985-1986) 95 Yale LJ at 1605 [Cover "Violence"]. For a similar view, see Taiaiake Alfred, Wasáse: Indigenous pathways of action and freedom (Peterborough: Broadview Press, 2005) at 7 [Alfred, Wasáse].

56 James (Sákéj) Youngblood Henderson, “Aboriginal Jurisprudence and Rights” in Wilkins, supra note 35 at 71 [Henderson "Jurisprudence"]. 
Indigenous legal systems are dynamic processes that manifest through the conduct of community members - through the ways in which Indigenous peoples interact with the world around them. These systems often are reinforced through ceremony and ritual. Such legal systems, rather than being conceived as separate from everyday existence, are integrated into Indigenous peoples' every day lives.

\section{Narrative, Mythology, Language and Literature in Indigenous Legal Traditions}

Jurisgenerative communities create legal systems that are not only made up of laws but also of narrative, myth, language, and literature. ${ }^{57}$ Cover asserts that "no set of legal institutions or prescriptions exists apart from the narratives that locate it and give it meaning. ${ }^{58}$ Narratives provide the context that contributes to the creation of legal meaning in a particular culture; "[i]n this normative world, law and narrative are inseparably related. Every prescription is insistent in its demand to be located in discourse - to be supplied with history and destiny, beginning and end, explanation and purpose." ${ }^{59}$ Law, therefore, relies on narrative for its location in a particular historical context and for an explanation of its purpose.

In Indigenous cultures, narrative is extremely important in the creation and perpetuation of legal meaning. Oral history is an integral part of Indigenous cultures and plays an important role in the creation of the normative worlds of Indigenous communities. In the Nisga'a culture, for example, the adaawak tells the story of the creation of the Nisga'a people and sets out their tribal laws. ${ }^{60}$ Oral history creates a record of the past and of significant events in a First Nation's history, which passes from generation to generation in order to locate the Nation in its particular historical and cultural context. These narratives also inform and contribute to the creation of Indigenous normative legal systems.

Indigenous peoples' oral histories have been devalued and misunderstood in the non-Indigenous legal system. ${ }^{61}$ As Patricia Monture claims:

Oral history is... a concept that is not well understood. Having a culture based on oral history means something greater than valuing the spoken word over the written word. It is an entire process of accurately recording history. The courts have tended

57 Cover, "Nomos", supra note 30 at 9.

58 Ibid at 4. In "Apocryphal Jurisprudence" (2001) 23 Stud in Law Politics \& Society 81, Desmond Manderson makes a similar argument. Like Cover, Manderson asserts that mythology and narrative have an important role to play in the creation of legal meaning.

59 Cover, "Nomos", supra note 30 at 5.

60 Rod Robinson (Sim'oogit Minee'eskw), "Nisga’a Patience: Negotiating Our Way Into Canada" in John Bird, Lorraine Land \& Murray MacAdam, eds, Nation to Nation: Aboriginal Sovereignty and the Future of Canada (Toronto: Irwin Publishing, 2002) at 186-187. Similarly, in Gitksan culture, the ada'ox plays a central role: see Peter Knudtson \& David Suzuki, Wisdom of the Elders (Toronto: Stoddard Publishing, 1992) at 128.

61 To see a prime example of the devaluation of oral history, see Delgamuиkw v British Columbia [1991] BCJ No 525 (BCSC). On appeal by the Gitskan and Wet'suwet'en, however, in Delgamuиkw, supra note 43, the Supreme Court of Canada ordered a new trial because the trial judge had not given any independent weight to oral history. For other cases where oral history evidence has not been given due weight see $R v$ Quinney, [2003] AJ no 313 (Prov Ct) [Quinney] at para 46; $R v$ Frank, [1999] AJ no 1074 (Prov Ct); and $R v$ Brertton, [1998] AJ no 257 (QB) at para 74. 
to simplify the process of oral history and treat it as something less advanced than recording history on paper. This fits very neatly with the 'noble savage' stereotype. This is wrong. What you can hold in your head cannot be taken from you and destroyed in the same way as a book can. The institution of oral history also ensures the passing down of history from generation to generation. ${ }^{62}$

Similarly, J. Edward Chamberlain highlights that oral texts are often reduced to the status of secondary documents based on the fact that "orality has often been considered according to a model that presumes literacy to be a step further along the evolutionary scale." ${ }^{63}$ The disjunction between oral history and the evidentiary rules in the non-Indigenous legal system is one manifestation of the different cultural values underpinning the two legal orders.

Sacred narratives also contribute to the creation of law. Cover asserts that "each community builds its bridges with the materials of sacred narrative that take as their subject much more than what is commonly conceived as the 'legal'." Sacred narratives have not always been seen as constitutive of law, however, Cover asserts that such narratives play a key role in the creation of legal meaning. He further suggests that "the commitments that are the material for our bridges to the future are learned and expressed through sacred stories." ${ }^{65}$ Since law is the committed social behaviour of the members of a community towards the creation of their visions of an alternative future, sacred narratives show members what their commitments are and how they are to act in order to bring such visions to life.

In the non-Indigenous legal system, the unwritten rules of the Constitution might be characterized as sacred narratives. ${ }^{66}$ Similarly, in many Indigenous communities within Canada, sacred narratives exist that set out their history, traditions, and legal principles. One such narrative is the Great Law of Peace of the Haudenosaunee Confederacy, which united five previously warring nations the Mohawk, Seneca, Onondaga, Oneida, and Cayuga. ${ }^{67}$ The Great Law of Peace sets out a complex political and legal system involving proportional representation of nations, veto powers, rules of order, and precedence in debate. ${ }^{68}$ A central concern of the Haudenosaunee system was that the Chiefs directly represent the

62 Monture, Journey, supra note 20 at 50-51.

J Edward Chamberlin, "Culture and Anarchy in Indian Country" in Michael Asch, ed, Aboriginal and Treaty Rights in Canada: Essays on Law, Equality and Respect for Difference (Vancouver: UBC Press, 1997) 3 at 8.

66 In several cases, the Supreme Court of Canada has held that unwritten principles can inform interpretations of the Constitution and include federalism, democracy, constitutionalism and the rule of law, and respect for minority rights: see Reference re Secession of Quebec, [1998] 2 SCR 217 [Secession Reference] at para 50. Another case dealing with the unwritten principles of the Constitution is Reference re Remuneration of Judges of the Provincial Court of Prince Edward Island, [1997] 3 SCR 3.

67 Alfred, Heeding the Voices, supra note 1 at 77-78.

68

Ibid. 
will of the people. As a result, the two main features of the Haudenosaunee system were consensual decision-making and a participatory political structure.

Just as narrative plays a central role in locating the members of Indigenous communities within their normative worlds and elucidating the values central to Indigenous' cultures, so does mythology. ${ }^{70}$ Mythology plays a key role in the perpetuation of community, identity, and social values for Indigenous peoples. Gary Snyder argues: "mythology is the central patterning force of...verbal organization which survives through generations, containing the cosmology and value-system of the group." ${ }^{, 71}$ Further, myths works together to create a more complete picture of the values of a particular community; some theorists assert that it is integral to understand all the mythology of a culture and how the various myths inform one another in order to understand the values of that culture. ${ }^{72}$ Mythology, therefore, helps members of a particular culture make sense of their place in the world. ${ }^{73}$

The language of a culture also contributes to the creation of legal meaning. In the context of the Canadian legal system, the language of rights is paramount. As Cover describes:

The story behind the term "rights" is the story of social contract. The myth postulates free and independent if highly vulnerable beings who voluntarily trade a portion of their autonomy for a measure of collective security. The myth makes the collective arrangement the product of individual choice and thus secondary to the individual. "Rights" are the fundamental category because it is the normative category which most nearly approximates that which is the source of the legitimacy of everything else. Rights are traded for collective security. But some rights are retained and, in some theories, some rights are inalienable. In any event the first and fundamental unit is the individual and "rights" locate him as an individual separate and apart from every other individual.

69 Ibid.

70 Stan McKay, "Rooted in Creation" in Bird, Land \& MacAdam, supra note 60 at 30.

71 Gary Snyder, He Who Hunted Birds in His Father's Village: The Dimensions of a Haida Myth (Bolinas, CA: Grey Fox Publishing, 1979) at 109.

72 Claude Lévi-Strauss, Structural Anthropology (Harmondsworth: Penguin, 1968) at Ch XI cited by Fitzpatrick, supra note 22 at 21.

73 Robert Bringhurst, A Story as Sharp as a Knife: The Classical Haida Mythtellers and Their World (Lincoln, NE: University of Nebraska Press, 1999) at 288. In Cover, "Folktales", supra note 54 at 190, Cover explains that myth and history play different roles in the creation of legal meaning: "Myth is the part of reality we create and choose to remember in order to reenact. It is intensely personal and committed. History is the countermove bringing us back to reality, requiring that we test the aspiration objectively and prudentially. History corrects for the scale of heroics that we would otherwise project upon the past. Only myth tells us who we would become; only history can tell us how hard it will really be to become that."

74 Robert Cover, "Obligation: A Jewish Jurisprudence of the Social Order" in Martha Minow, Michael Ryan \& Austin Sarat, eds, Narrative, Violence, and the Law: The Essays of Robert Cover (Ann Arbor: University of Michigan Press, 1992) at 240 [Cover "Obligation"]. Here Cover discusses the US system but his analysis of the importance of rights discourse is just as relevant to the Canadian context. 
In the Canadian legal system, rights are the fundamental unit and, based on this theory, individual rights take precedence over collective rights.

Some Indigenous theorists have argued that the language of rights does not coincide with Indigenous worldviews. As Osennontion and Skonaganichira describe:

We have a law that came from the creator and in that law was absolutely everything that we needed! Kanien'keha:ka call it the KAIANERE'KO:WA. Some people call it the Great Law, or the Great Law of Peace, and it is. This law, our law, does not define "rights"; it does not defend "rights." In our ways, there are no "rights," only responsibilities: to observe the clans, to bring honour, trust, friendship and respect; to share; to be kind, honest and knowledgeable; to maintain a relationship with all of the natural world. ${ }^{76}$

Similarly, other Indigenous theorists stress the importance of responsibilities rather than rights within Indigenous legal traditions. ${ }^{77}$ The language of rights may not accurately reflect the values of Indigenous cultures, rather responsibilities form the central basis around which Indigenous legal systems evolve. ${ }^{78}$

In his critique of the limitations of liberalism in protecting the interests of Aboriginal peoples, Gordon Christie highlights the focus on responsibilities in Indigenous cultures:

[I]n Aboriginal communities the ways of living valued and promoted are such as to require years of gentle instruction, a process of maturation aided by a community's careful system of guidance. Central to this process or moral education is building a core sense of responsibility, one which would come to be an integral part of one's sense of personal identity. One threat of liberalism and many critical alternatives is to that core sense of

75 See Mary Ellen Turpel, "Home/Land” (1991) 10 Can J Fam L 17 [Turpel "Home/Land"]; see also Turpel, "Interpretive Monopolies", supra note 1; and see also Gerald R Alfred, Peace, Power, Righteousness: An Indigenous Manifesto (Toronto: Oxford University Press, 1999) at 140 [Alfred, Manifesto].

76 Osennontion \& Skonaganichira, "Our World" (1989) 10 Canadian Journal of Women’s Studies 7. For a contrasting view of the usefulness of rights discourse in Indigenous' struggles and the ability of Indigenous peoples to transform such discourse see John Borrows, "Contemporary Traditional Equality: The Effect of the Charter on First Nation Politics" (1994) 43 UNBLJ 19 at 20-21.

77 See Turpel, "Interpretive Monopolies, supra note 1 at 143; see also Patricia A Monture-Okanee \& Mary Ellen Turpel, "Aboriginal Peoples and Canadian Criminal Law: Rethinking Justice" (1992) UBC L Rev 239 at paras 19-20; see Oren Lyons, "Traditional Native Philosophies Relating to Aboriginal Rights" in Menno Boldt \& J Anthony Long, eds, The Quest for Justice: Aboriginal Peoples and Aboriginal Rights (Toronto: University of Toronto Press, 1985); see Patricia A Monture-Okanee, "The Roles and Responsibilities of Aboriginal Women: Reclaiming Justice" (1992) 56 Sask L Rev 237 at 260, 262 \& 265; and see Andrea Bear Nicholas, "Canada's Colonial Mission: The Great White Bird" at 14, online: Native Studies Program, St. Thomas University <http://www.nativestudies.org/native_pdf/canadascolonialmission.pdf>. 
responsibility. This sense must be carefully instilled, carefully nurtured and carefully maintained. An individual possessed of this sense will know what to do and how to act so as to travel the good path, to live a good life. This involves, essentially, doing as one must towards fellow beings, both human and non-human. The introduction of liberalism threatens to undercut this carefully balanced existence, for it suggests to the individual that the community has no inherent value, that others only have value in relation to one's own self-examined beliefs and that one has no inherent responsibilities to any being other than oneself. ${ }^{79}$

The focus on responsibilities and community rather than rights or entitlements differentiates Indigenous from non-Indigenous cultures in ways that may make the application of a legal system founded upon liberal values an uneasy fit to appropriately resolving disputes involving Indigenous communities.

The disjunction between rights and responsibilities is but one manifestation of the failure of communication between non-Indigenous and Indigenous systems. The language of the non-Indigenous legal system may not be able to appropriately reflect Indigenous realities. As Jean-François Lyotard explains, a case of "differend" occurs when a conflict occurs between two parties that is regulated in the idiom of one of the parties while the wrong suffered by the other is not signified in that idiom. ${ }^{80}$ The wrong suffered by Indigenous claimants may not be able to be cognizably communicated to a judge in the non-Indigenous legal system. $^{81}$ Moreover, "a translation from one language to another presupposes that the sense presented by a phrase in the language of departure can be recovered by a phrase in the language of arrival.". ${ }^{, 22}$ Such translation may not easily be achieved in the context of Aboriginal claims since the cultural values of Indigenous peoples are vastly different than those underpinning the non-Indigenous system.

The literature of a particular legal system plays an important role in the creation of legal meaning and within that literature there are canonical texts - those considered authoritative - and countertexts - those that challenge the authority of canonical texts. The Constitution Act is arguably a canonical text of the Canadian legal system. ${ }^{83}$ As Joseph Carman Smith and David Weisstub observe:

79 Christie, "Law, Theory", supra note 48 at para 106.

80 Jean-François Lyotard, The Differend: Phrases in Dispute translated by Georges Van Den Abbeele (Minneapolis: University of Minnesota Press, 1988) at 9.

81 Ibid at 30.

$82 \quad$ Ibid at 48-49.

83 In Cover, "Nomos", supra note 30 at 17, he argues that although some texts, such as the U.S. Constitution, are seen as canonical, "the meaning of such a text is "essentially contested"" in that "[a]ll Americans...do not share an authoritative narrative regarding its significance." This argument is valid and applicable in the context of Indigenous peoples within Canada since some Indigenous peoples have differing conceptions of the meaning of the Canadian Constitution in their lives. Some Indigenous peoples have argued that they stand in a unique position in relation to the Constitution since they neither had input into the design of the Constitution nor have they agreed to live under the authority of the Constitution. For a discussion of this view see Monture, Journey, supra note 20 at 53-54; see also George Erasmus \& Joe Sanders, "Canadian History: An Aboriginal Perspective" in Bird, Land \& MacAdam, supra note 60 at 7; and see also Minow, "Introduction: Robert Cover and Law, Judging, and Violence" in Minow, Ryan \& Sarat, supra note 74 at footnote 19 . 
Cultures have critical moments in history when their values are constitutionally structured according to a legal design. The Magna Carta and the American Constitution are both examples of such an historical birth. These constitutional statements embody the most foundational values that the society commits itself to at the time. When this is accomplished in law it means that the society undertakes to harness its energies to ensure that these values are protected and that the future of the society is shaped by them. The constitutional document then serves as monitor of the society's conduct. ${ }^{84}$

The Constitution embodies a particular cultural perspective of the foundational values of Canadian society and of the future of our society. The canonical narrative of the Constitution exhaustively divides governmental powers between the Canadian federal government and the provinces and establishes one legal system to govern the entire country. This canonical narrative also tells the story that Indigenous peoples extinguished their claims to land and to sovereign governments upon the arrival of the Europeans.

The British Columbia Supreme Court [BCSC] exposed the mythology underpinning the canonical narrative underlying the division of powers in the Constitution in Campbell v British Columbia. ${ }^{85}$ In Campbell, three members of the British Columbia Legislative Assembly asserted, among other things, that the Nisga'a Treaty was unconstitutional because it created a "new order of government" ${ }^{46}$ in granting jurisdiction to the Nisga' a government in contravention of the exhaustive division of powers in the Constitution. ${ }^{87}$ The BCSC upheld the constitutionality of the Nisga'a Treaty, finding that the division of powers in the Constitution only divided the powers previously held by the colonies. The Court held that Aboriginal rights remained in force pursuant to Imperial legal principles, which recognized a continuing, diminished form of Aboriginal self-government after the assertion of Crown sovereignty. ${ }^{88}$

Indigenous peoples' narratives, mythologies, and oral histories also act to expose the mythology underpinning the canonical narrative of the exhaustive division of powers in the Constitution. The narrative of the Great Law of Peace gives us a different view of the history of Canada - a view in which five sovereign nations developed a highly complex system of consensus-based government to ensure their peaceful co-existence. This countertextual narrative supports the view that Indigenous peoples within Canada had pre-existing legal and political systems to effectively govern their internal and international affairs. Viewed through the lens of this countertext, the early treaties signed between the colonizers and Indigenous peoples represented sovereign agreements between nations.

\footnotetext{
84 Joseph Carman Smith \& David N Weisstub, The Western Idea of Law (Toronto: Butterworths, 1983) at vii-viii. 
Because the creation of legal meaning takes place within a particular culture, in order to understand law it is imperative that one also understands the traditions and the literature of that culture. ${ }^{90}$ Such understanding may not be easily accessible by outsiders to the culture, therefore, non-Indigenous judges may not be in the best position to determine the content or interpret Indigenous legal traditions. As Mary Ellen Turpel asserts: "[i]n order to be sensitive [to the cultural differences between Aboriginal and non-Aboriginal peoples], the court would have to allow for the fact that an entirely different conceptual framework may apply and that they (the judiciary) are not capable of knowing or reconciling the differences. ${ }^{, 11}$ This reality is compounded by the fact that Canadian cases to date have generally upheld the status quo of social power, which relegates Indigenous peoples' interests to the margins and fails to appropriately remedy the vast disparity in material conditions affecting Indigenous communities. As long as these social, economic and political disparities continue, Indigenous legal traditions and the narratives, myths, and languages embodied within them may be gutted of practical content, for they may find little room for expression in the material conditions constraining Indigenous communities.

Because judges are not in a position to understand First Nations' literatures and traditions, non-Indigenous courts have failed to accurately define the content of Aboriginal rights under Canadian law. ${ }^{93}$ Henderson argues that since Aboriginal rights are sui generis, meaning of their own kind, and because these rights preexist the creation of the Canadian state, courts are required to look to Indigenous legal systems to determine the content of such rights. ${ }^{94}$ Because they are not privy to the language and cultures of the Indigenous peoples with whom they are interacting, non-Indigenous judges have not been able to effectively define Aboriginal rights.

Although mythology, narrative and language play a central role in both nonIndigenous and Indigenous legal systems, these myths, narratives and languages are radically different based on cultural and historical contingency. As such, when Indigenous claimants bring their claims to non-Indigenous courts, a very real possibility arises that there could be a massive communication gap between the cultures and that any decision based on Eurocentric cultural values may fail to fairly resolve Aboriginal claims.

\section{LAW AS VIOLENCE}

Some theorists characterize state legal systems as violent. Law, according to Cover, is infused with violence since when "a judge articulates her understanding

Surviving as Indians: The Challenge of Self-Government (Toronto: University of Toronto Press, 1993) at 41.

90 Cover "Folktales", supra note 54 at 182. Cover says that "the claim to a "law' is a claim as well to an understanding of literature and tradition."

$91 \quad$ Ibid at 142.

92 See supra note 42.

93 Henderson, "Jurisprudence", supra note 56 at 73.

94 Ibid at 70. In "With or Without You: First Nations Law (in Canada)" (1996) 41 McGill LJ 629 at 636, John Borrows makes a similar argument.

95 Henderson, "Jurisprudence", supra note 56 at 72. 
of a text...somebody loses his freedom, his property, his children, even his life." ${ }^{96}$ In this view, judges choose interpretations of law that reinforce the status quo and state law contributes to the silencing of alternative legal forms by backing those choices with state power. In Cover's view, the legal system is an organized, social practice of coercion, ${ }^{97}$ which is backed by the power of the state to enforce violence on those who come before it. ${ }^{98}$

One manifestation of the violence of the legal system is the jurispathic role of judges. ${ }^{99}$ Cover argues that judges are "jurispathic, they kill the diverse legal traditions that compete with the state." $\mathrm{He}$ asserts: "Judges are people of violence. Because of the violence they command, judges characteristically do not create law, but kill it. Theirs is the jurispathic office. Confronting the luxuriant growth of a hundred legal traditions, they assert that this one is the law and destroy or try to destroy the rest." "101 The judge's decision reflects his or her choice between the plethora of legal interpretations, which embody the values of different normative communities. In making their decisions, judges quash alternative interpretations of law by imposing their own legal interpretation and claiming it as authoritative.

If one accepts that state legal systems are inherently violent in establishing and reinforcing the state's interpretation of law as authoritative, it might be useful to consider how the legal system disguises the violence at its root. In his critique of the Canadian legal system, Roberto Unger argues that judges use the strategy of rationalizing legal analysis to justify their interpretations of law as authoritative. Rationalizing legal analysis creates the illusion that the legal system is based upon immutable values and rights thereby justifying the structure of the legal system itself. $^{102}$ The court system is therefore both unwilling and unable to challenge its own authority since the constraints of its structure dictate that its decisions must reinforce the values underlying that structure.

In asserting that judges' interpretations of law are authoritative, judges construct their vision of law as both legitimate and inevitable. ${ }^{104}$ In effect, law is "a means of advancing and legitimating political positions and of mystifying and concealing the very existence of those positions."

Cover, "Nomos" supra note 30 at 17

Ibid.

98 Ibid at 1607; see also Cover, "The Bonds of Constitutional Interpretation: Of the Word, the Deed, and the Role" (1986) 20 Ga L Rev 815 at 819 [Cover, "Bonds"].

In Cover, "Nomos", supra note 30 at 57 , he also asserts that judges commit acts of violence when they fail to challenge the state's violence by using the principle of deference in resorting to what he calls 'the texts of jurisdiction'.

100 Cover, "Bonds", supra note 98 at 819 . In his commentary on the Supreme Court of Canada's decisions in Aboriginal rights cases, Henderson echoes the view of courts as jurispathic: see Henderson, "Jurisprudence", supra note 56 at 76.

101 Cover, "Nomos" supra note 30 at 53. Cover also asserts that "judges are also people of peace. Among warring sects, each of which wraps itself in the mantle of a law of its own, they assert a regulative function that permits a life of law rather than violence."

102 Lorne Sossin, "The Politics of Imagination" (1997) 47 UTLJ 523 at 525.

103 For a case that exemplifies this reasoning, see Mitchell, supra note 42.

104 Sossin, supra note 102 at 525.

105

Harry William Arthurs, Without the Law: Administrative Justice and the Legal Pluralism in Nineteenth-Century England (Toronto: University of Toronto Press, 1985) at 11. 
legal system is constructed as rational, natural, and necessary and its construction as such is concealed.

In positioning their vision of law as legitimate and inevitable, judges dichotomize alternative interpretations of legal meaning as unnatural, irrational, and unnecessary. ${ }^{106}$ Mary Ellen Turpel argues that "law constructs authoritative visions of a social and political world, sanctioning particular images of reality while effectively silencing other (namely aboriginal) visions." ${ }^{107}$ Any creation of legal meaning that diverges substantially from that of the judges' imposed legal meaning, therefore, will be resisted as illegitimate.

Lyotard argues that in order to mask the failure of communication or differend, one party assumes a monopoly over the procedures for establishing historicalpolitical reality. ${ }^{108}$ In his view, the tribunal charged with resolving the litigation derives its authority from that monopoly and therefore the litigation is always regulated to the advantage of the monopoly. ${ }^{109}$ Lyotard's view supports the idea that the non-Indigenous legal system is designed to justify the dominance of Eurocentric ideology and marginalize Indigenous understandings of law.

Although non-Indigenous legal institutions are constructed as natural, the institutions are in fact contingent. ${ }^{110}$ By admitting an institution is contingent, one can then contest its content. ${ }^{111}$ Cover points out that

the very structure of the mind of the decisionmaker is challenged once one argues that it is a socially contingent apparatus and that it is functionally related to the needs and experiences of the group characterized by that structure. For, if the dispute in question can be fairly understood as intergroup in some sense, then the question that begs for an answer is why does the ideology of this group, rather than that of its antagonist, determine the outcome.

By recognizing the contingency of the structures underpinning the non-Indigenous legal system, we can reconstruct this system in new, more inclusive ways. One possibility is to construct multiple sets of legal institutions that embody the diversity of Indigenous peoples' normative worlds in order to reflect Indigenous cultures more accurately.

The contingency of the structure of the legal system in our society highlights the inherent conflict of interest with which judges in the non-Indigenous legal system are faced. ${ }^{113}$ The constraints of the legal system, through its discourse,

106 Sossin, supra note 102 at 524.

107 Turpel, "Home/Land", supra note 75 at 21.

108 Lyotard, supra note 80 at 172.

109 Ibid at 173

110 Unger, supra note 12 at 167.

111 Ibid. See also Sossin, supra note 102 at 533.

112 Cover, "The Uses of Jurisdictional Redundancy: Interest, Ideology, and Innovation” in Minow, Ryan \& Sarat, supra note 74 at 76 [Cover, "Redundancy"].

113 In "The Origins of Judicial Activism in the Protection of Minorities" in Minow, Ryan \& Sarat, supra note 74 at 34 , Cover's discussion of the difference between courts' decisions in the context of the minorities subject to occasional mistreatment and those subject to a pervasive pattern of 
narratives, and history, make it difficult, if not impossible, for judges to determine the outcomes in Aboriginal rights cases in a way that takes into account the normative values of Indigenous communities. When faced with such claims, therefore, judges choose legal interpretations that reinforce the principles upon which the non-Indigenous legal system is based - principles based on a history of colonialism and on the oppression of Indigenous peoples within Canada.

Cover asserts that the resistance of a normative community to the nation state's legal system forces that community to revise its legal interpretations:

Whenever a community resists a rule of silence or some other law of the state, it necessarily enters into a secondary hermeneutic - the interpretation of the texts of resistance. For a group to live its law in the face of the predictable employment of violence against it requires a new elaboration of "law" - the development of an understanding that what is right and just in the violent contexts that the group will encounter. The group must understand the normative implications of the struggle and the meaning of the suffering and must accept responsibility for the results of the confrontations that will ensue.

Indigenous peoples within Canada continue to resist the violence of the nonIndigenous legal system. They continue to assert, despite assimilative governmental policies and laws, unique visions of their normative worlds through adherence to legal traditions that reflect their cultural values. Through such resistance, Indigenous communities challenge the non-Indigenous legal system's claim to authoritative interpretation.

In order to recognize meaningfully the validity of Indigenous legal traditions, it is necessary to avoid replicating the existing power dynamic between colonizer and colonized. ${ }^{115}$ The danger of incorporating Indigenous legal traditions within the non-Indigenous legal system is that judges in that system are not privy to the traditions, narratives, myths, and languages that reflect the normative values of Indigenous communities. The incorporation of Indigenous legal traditions within the non-Indigenous legal system is subject to the dangers of assimilation, colonization, and appropriation. If Indigenous legal traditions are not given room to flourish on their own terms, the non-Indigenous legal system will continue to exert violence in the lives of Indigenous peoples within Canada.

oppression is particularly relevant to Indigenous communities within Canada. He says:

"[i]ntermittent judicial intervention may be justified in (and suited to) correcting oppression identified as an aberration, a single perversion of majoritarian politics. But when the oppression of a minority comes to constitute the essence of those politics or - still worse - when the constitutional structure for political activity has been arranged to facilitate the pattern of oppression, judicial intervention will necessarily entail either inefficacy or a compromise in the constitutional structure itself."

114 Cover, "Nomos", supra note 30 at 49. For a similar argument, see Alfred, Wasáse, supra note 55 at 47.

115 Michel Foucault, "Two Lectures" in Power/Knowledge: Selected Interviews and Other Writing 1972-1977, ed \& translated by Colin Gordon (Brighton: Harvester Press, 1980) at 86. 


\section{LAW AS EQUALLY VALID AND INCOMMENSURABLE}

The non-Indigenous legal system is designed to exert violence on alternative legal systems by insisting that its vision of law is authoritative. In light of this design, the question remains: how might the Indigenous legal traditions be encouraged to flourish without the exertion of such violence? Cover urges us to "grant all collective behavior entailing systemic understandings of our commitments to future worlds equal claim to the word "law"" ${ }^{116}$ Cover acknowledges that if we were to do this, the nation state's law would not be granted special status and instead would be understood as just one of many valid social understandings of law. ${ }^{117}$ The question of what law is would then not be solely the question of what the state says law is, but instead could be answered in a multitude of different ways depending on which community is answering the question.

In urging us to give jurisgenerative communities equal claim to the word law, Cover suggests that there is inherent value in the continued existence of diverse legal systems. Similarly, Kymlicka asserts that cultural diversity is "valuable, both in a quasi-aesthetic sense that it creates a more interesting world, and because other cultures contain alternative models of social organization that may be useful in adapting to new circumstances." ${ }^{118}$ Cultural diversity, reflected through diverse legal traditions is valuable in that legal systems emanating out of different normative worlds may in fact create more justice, fairness, and better law than the present legal system.

Currently, non-Indigenous judges are not well versed in the cultural traditions and values of most Indigenous communities in Canada. Henderson asserts that in order for the non-Indigenous legal community to take full account of Indigenous legal systems to accurately define Aboriginal rights, "non-Aboriginal scholars and judges will have to learn Aboriginal languages and jurisprudences." ${ }^{119}$ The experience of anthropologists shows us that understanding the intricacies of Indigenous cultures is a difficult task. As Clifford Geertz asserts: "[u]nderstanding the form and pressure of...natives' inner lives is more like grasping a proverb, catching an allusion, seeing a joke - or...reading a poem - than it is like achieving communion." ${ }^{120}$ Due to the diversity among Indigenous communities within Canada and the difficulty of understanding the intricacies of such cultures, it may not be realistic for judges to develop expertise in the languages and legal systems of each Indigenous community that brings its claims to Canadian courts.

The difficulty of learning about Indigenous cultural values and legal systems is compounded by the fact that in some Indigenous cultures, it is forbidden for members of that culture to share their oral histories with outsiders. In Nisga'a culture, for example, "the ancient law...forbids the telling of one's history to another, other than within one's own tribe. It is also illegal to tell the history of

\footnotetext{
116 Cover, "Folktales", supra note 54 at 181.

117 Ibid at 182

118 Will Kymlicka, Multicultural Citizenship (Oxford: Clarendon Press, 1995) at 121.

119 Henderson, "Jurisprudence", supra note 56 at 73 \& 77.

120 Clifford Geertz, Local Knowledge: Further Essays in Interpretive Anthropology (New York: Basic Books, 1983) at 59.
} 
another tribe." ${ }^{121}$ Due to the difficulty of accessing the requisite information to understand diverse Indigenous cultures, it may be necessary for non-Indigenous judges to recognize the limits of their perspectives and the limits of nonIndigenous legal principles in establishing fair and just results in litigation involving Indigenous peoples.

Non-Indigenous judges have an important role to play in affirming the existence and validity of the multiple legal systems of jurisgenerative communities. Cover asserts that "the commitment to a jurisgenerative process that does not defer to the violence of administration is the judge's only hope of partially extricating himself from the violence of the state." ${ }^{122}$ In recognizing the limits of their perspectives and knowledge with respect to Indigenous cultures, non-Indigenous judges can play a vital role in affirming the inherent value of Indigenous legal traditions.

If we accept Cover's assertion that the law of each normative community should be considered equally valid, we end up with conflicting systems of law: " $[t]$ he challenge presented by the absence of a single, 'objective' interpretation is...the need to maintain a sense of legal meaning despite the destruction of any pretense of superiority of one nomos over another." ${ }^{124}$ With competing legal orders, the difficulty becomes how might we create a world in which multiple legal systems exist and are encouraged to flourish.

Incommensurability is a useful theory in thinking through the conflict between normative legal systems. The concept of incommensurability involves the notion that two things cannot be compared or measured because there is no common standard or neutral experience to allow for the comparison to take place. ${ }^{125}$ As Patrick Glenn explains,

Joseph Raz has set out what has been described as the 'logical possibility" of incommensurability. Thus: "A and $\mathrm{B}$ are incommensurate if it is neither true that one is better than the other nor true that they are of equal value." There is thus incommensurability if we are unable to evaluate A or B, in terms of their relation to one another, and this because there is not means or scale of evaluation of them. Incommensurability is equivalent to incomparability. ${ }^{126}$

121 Robinson, supra note 60 at 187. There are similar rules in other Indigenous cultures. For example, in the Australian case, Chapman v Luminis Pty Ltd (2002) (No 4) 123 FCR 62, relating to the Hindmarsh Island bridge controversy, several Ngarrindjeri female Elders claimed that the waters where the bridge would be constructed were spiritually significant but refused to share their oral traditions in relation to this knowledge because it was forbidden under their law.

122 Cover, "Nomos", supra note 30 at 59.

123 In "Folktales of Justice", supra note 54 at 203, Cover asserts that judges need to make normative statements in deciding cases in order to contribute to the creation of a better world. He asserts that "it is only that which redeems which is law." Redemption, by Cover's definition, connotes the saving or freeing of persons, worlds or understandings.

124 Cover, "Nomos", supra note 30 at 44.

125 H Patrick Glenn, “Are Legal Traditions Incommensurable?” (2001) 49 Am J Comp L 133 at 134. Some theorists do not accept that incommensurability is equivalent to incomparability. As a result, my use of the term incommensurability includes the recognition that two things may not be measurable.

126 Ibid at 135. 
Incommensurability results, therefore, when there is no way to compare or measure two different things. Similarly, incommensurability occurs when there is no way to accurately signify the reality of Indigenous people within the language of the non-Indigenous legal system. ${ }^{127}$ Within the non-Indigenous system, there is a particular way that the universe is presented (i.e. colonizer as enlightened/colonized as savage) that does not accurately reflect Indigenous worldviews.

In the context of multiple normative legal systems, the concept of incommensurability is helpful because it "allows us to consider some things as intrinsically good in themselves, protecting them from the imperialism of the single, great values." ${ }^{128}$ The recognition of incommensurability allows for the existence of multiple legal systems and allows for the valid recognition of such systems.

The notion of incommensurability, however, has some drawbacks. Glenn argues that "[t]here is an extremely high cost to incommensurability, since if it exists within cultures it is certain to exist across cultures and there would then be a kind of massive communication failure in the world, an inherent clash of civilizations." ${ }^{129}$ To recognize that incommensurability exists across cultures allows for the possibility that different cultural traditions, values, and legal systems may remain purely untranslatable from one culture to another.

The converse of incommensurability includes theories that embrace commensurability. Commensurability rests on the notion that "every choice involves comparisons along a single dimension of value". ${ }^{130}$ In Plato's discussion of commensurability, he argues that love can be compared to mathematics, to politics, and to anything else one can imagine. ${ }^{131}$ In her discussion of Plato's theory of commensurability, Nussbaum says: "[i]t is a startling and powerful vision. Just try to think it seriously: this body of this wonderful beloved person is exactly the same in quality as that person's mind and inner life. Both, in turn, the same in quality as the value of Athenian democracy; of Pythagorean geometry; of Eudoxan astronomy." "132 Here Nussbaum explains that commensurability creates the ability to compare all things even though they seem incomparable or immeasurable on the surface.

The advantage of theories of commensurability is that if one adopts the view that all things are commensurable then "we can then lead a life free of disturbing pains and intolerable conflicts." perspective of commensurability because then choices will all be comparable: "what is measurable or commensurable is graspable, in order, good; what is without measure is boundless, elusive, chaotic, threatening, bad." ${ }^{134}$ Once people

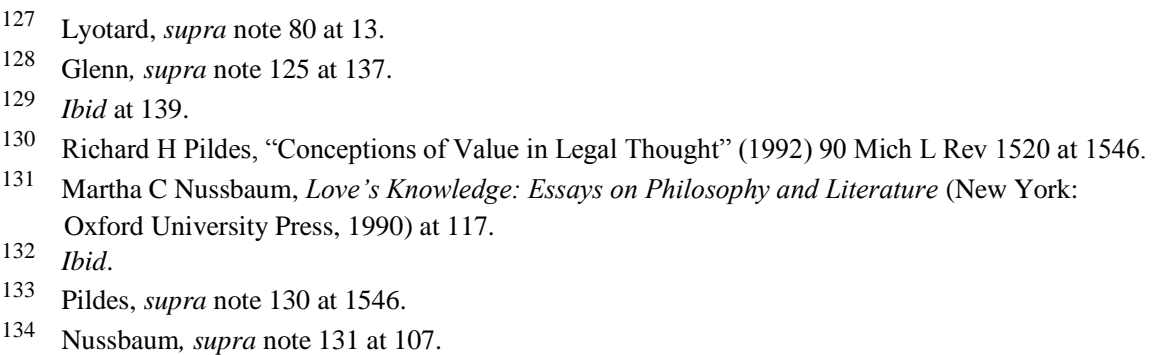


embrace the theory of commensurability choices become simpler because one can always measure which choice is better.

In its imposition of the single, great values, commensurability mirrors the jurispathic nature of state legal systems. Because of the imposition of such values, commensurability would not allow for the existence of multiple legal systems based on different normative values. Commensurability, therefore, is dangerous because it leads to the imposition of a single value in order to facilitate comparison or measurement. Within the non-Indigenous legal system, this single value inevitably will be drawn from Eurocentric value systems with a view to reinforcing the power dynamics at the heart of the colonial domination of Indigenous communities.

Incommensurability allows for the recognition of multiple legal systems. However, recognizing incommensurability within the non-Indigenous legal system is a challenging proposition. As Glenn argues, "[i]ncommensurability within a legal tradition is something which no legal tradition has ever acknowledged and which no legal tradition ever could acknowledge, since this would imply a form of schism incompatible with the ongoing normativity of the tradition, for all adherents to the tradition." ${ }^{135}$ Our legal system resists the recognition of incommensurability because it is premised on the notion that there are universal values that are equally valid and true for every person in Canada. Incommensurability challenges the proposition that these values exist and challenges the assumption that the Canadian legal system is the only forum for the creation of law in Canada.

The recognition of incommensurability between the cultural values underpinning the non-Indigenous legal system and those underpinning Indigenous legal traditions is one way in which to promote the continued existence of a multiplicity of normative legal systems. This recognition shows respect for the reality that Indigenous peoples "are oriented as wholes in different directions in pursuit of different ends, and these ends and these means in one society cannot be judged in terms of those of another society because essentially they are incommensurable. ${ }^{136}$ Although challenging, the recognition of incommensurability within the non-Indigenous legal system may lead to the practical implementation of alternative forums $^{137}$ that embody multiple legal systems and better reflect Indigenous values.

135 Glenn, supra note 125 at 142.

136

Mary Ellen Turpel, "Aboriginal People and the Canadian Charter of Rights and Freedoms: Contradictions and Challenges" (1989) 10 (2\&3) Canadian Women's Studies 149 at 150. Here Turpel cites and modifies Ruth Benedict's language in Patterns of Culture (London: Routledge \& Kegan Paul Ltd. 1935) at 161.

137 There are several examples in Canada of alternative forums that are specifically set up to deal with Indigenous claims in a culturally appropriate manner. These include: the Gladue Courts in Toronto, the Tsuu T'ina First Nation Court in Alberta, the Metis Settlements Appeal Tribunal in Alberta, the Nunavut Court of Justice and the peacemaker court of the Teslin Tlingit First Nation in the Yukon. For a discussion of some of these initiatives, see Catherine Bell, "Indigenous Dispute Resolution Systems within Non-Indigenous Frameworks: Intercultural Dispute Resolution Initiatives in Canada" in Catherine Bell \& David Kahane, eds, Intercultural Dispute Resolution in Aboriginal Contexts (Vancouver: University of British Columbia Press, 2004) 241. 


\section{TOWARDS AN ALTERNATIVE FUTURE}

Indigenous peoples within Canada are rich in the diversity of their legal traditions. The diversity of these systems creates legal meaning that "is a challenging enrichment of social life [and] a potential restraint on arbitrary power and violence." ${ }^{138}$ The non-Indigenous legal system may not be the mechanism by which meaningful recognition of Indigenous legal traditions should take place. As Cover asserts:

[t]he statist impasse in constitutional creation must soon come to an end. When the end comes, it is unlikely to arrive via the Justices, accustomed as they are to casting their cautious eyes about, ferreting out jurisdictional excuses to avoid disrupting the orderly deployment of state power and privilege. It will likely come in some unruly movement - some undisciplined jurisgenerative impulse, some movement prepared to hold a vision in the face of the indifference or opposition of the state. ${ }^{139}$

Through their jurisgenerative actions, Indigenous peoples have proven that they are members of communities prepared to hold to their vision of an alternative future in the face of state opposition. Perhaps the non-Indigenous legal community can learn some valuable lessons from Indigenous legal systems in providing alternative visions of law reflecting the unique cultural values that form the basis of Indigenous legal traditions.

The recognition of Indigenous legal traditions as alternative spaces to create legal meaning provides the opportunity for much-needed reflection so that we can consider "a vision of how things are and might be... [and understand] the actual in light of the possible." ${ }^{140}$ The recognition of multiple legal systems from different communities is desirable in that it encourages alternative normative worlds to flourish. ${ }^{141}$ As a result, we may enable the creation of alternative structures built upon responsibility, reconciliation, and respectful co-existence. As Michael Ryan suggests, "[p]erhaps there should be a plurality of narratives, a multiple jurisgenerativity that exceeds any singular nomos or any decision between meanings." ${ }^{142}$ If Indigenous jurisgenerative communities are stifled, we will never know whether alternative legal systems based on different normative values would lead to more peace, justice, and fairness. Perhaps, as Cover suggests, "[w]e ought to stop circumscribing the nomos; we ought to invite new worlds." ${ }^{143}$

138 Cover, "Nomos", supra note 30 at 68.

139 Ibid.

140 Unger, supra note 12 at 24.

141 In Cover, "Redundancy", supra note 112 at 93, Cover argues that the fact that litigants can choose competing forums for their claims in different jurisdictions in the US is a positive attribute that supports the flourishing of normative legal systems.

142 Michael Ryan, "Meaning and Alternity" in Minow, Ryan \& Sarat, supra note 74 at 273. Ryan identifies the danger inherent in this proposition since "[n]ot all narratives tell nice stories".

143 Cover, "Nomos", supra note 30 at 68. 